Schulich School of Law, Dalhousie University

Schulich Law Scholars

Research Papers, Working Papers, Conference

Papers

Faculty Scholarship

2020

\title{
Disabling Solitary: An Anti-Carceral Critique of Canada's Solitary Confinement Litigation
}

Sheila Wildeman

Dalhousie University Schulich School of Law, sheila.wildeman@dal.ca

Follow this and additional works at: https://digitalcommons.schulichlaw.dal.ca/working_papers

Part of the Criminal Law Commons, Disability Law Commons, Human Rights Law Commons, and the Litigation Commons

\section{Recommended Citation}

Sheila Wildeman, "Disabling Solitary: An Anti-Carceral Critique of Canada's Solitary Confinement Litigation" in The Legacies of Institututionalisation: Disability, Law and Policy in the 'Deinstitutionalised' Community, Claire Spivakovsky, Linda Steele and Penelope Weller, eds (Oxford Hart, forthcoming 2020).

This Working Paper is brought to you for free and open access by the Faculty Scholarship at Schulich Law Scholars. It has been accepted for inclusion in Research Papers, Working Papers, Conference Papers by an authorized administrator of Schulich Law Scholars. For more information, please contact hannah.steeves@dal.ca. 


\section{Disabling Solitary: An Anti-Carceral Critique of Canada's Solitary Confinement Litigation}

[Pre-publication version of chapter for The Legacies of Institutionalisation: Disability, Law and Policy in the 'Deinstitutionalised' Community, Claire Spivakovsky, Linda Steele and Penelope Weller, eds (Oxford: Hart, 2020). Online version updated Apr 27, 2020, with further update and correction to footnotes $35 \& 37$ on Jan 1, 2022]

\section{SHEILA WILDEMAN}

The title of this chapter signifies at least three things. The first is the disabling effects of solitary confinement. The second is recent efforts of prison justice advocates in Canada to use law, or specifically litigation, to disable the logic of solitary confinement: to disrupt that logic through the logic of human rights. The third, most oblique reference, and one I develop here, speaks to dangers presented by the path Canada's solitary confinement litigation has taken: a path of isolating disability-based prison justice claims from the wider ambitions of intersectional substantive equality. My thesis is that this isolation of disability (specifically, mental disorder/disability) as the organising principle of solitary confinement's legally-cognisable harms has paradoxically re-inscribed and reinforced disability injustice, and with it, an array of interactive forms of social-structural oppression.

I situate my argument in the carceral studies tradition. ${ }^{1}$ This means examining the violence prisons do in light of a broader account of the social-structural violence through which white, colonialist, patriarchal and class supremacy is perpetuated. Recent work has brought together carceral studies with critical disability theory to explore the manifold ways the carceral state_ or "carceral archipelago"2_ responds to social-structural problems through strategies of isolation, confinement and control. ${ }^{3}$ On this analysis, the deep function of both penal and disability-based incarceration is to invisibilise the effects of gross inequality and attendant

\footnotetext{
${ }^{1}$ See eg M Brown and J Schept, 'New Abolition, Criminology and a Critical Carceral Studies' (2017) 19(4) Punishment \& Society 440.

${ }^{2}$ M Foucault, Discipline and Punish: The Birth of the Prison, trans. A. Sheridan (New York, Vintage, 1979$) 298$. ${ }^{3}$ See eg L Ben-Moshe, C Chapman and AC Carey (eds), Disability Incarcerated: Imprisonment and Disability in the United States and Canada (New York, Palgrave, 2014); M Segrave, C Spivakovsky and A Eriksson, 'The Maelstrom of Punishment, Mental Illness, Disability and Cognitive Impairment' (2017) 19:3 Punishment \& Society 267-271.
} 
material deprivation while legitimating the power and privilege of the dominant few. ${ }^{4}$ In other words, incarceration and other forms of carceral control reinforce the status of non-normate populations as unfit for equal social membership — dangerous, incapable, or both—while deepening their material disadvantage. My question is: Can law, or specifically litigation, help dismantle the interlocking institutions where carceral legitimation happens: the house(s) that law built? And if so, what is the role of disability in that work?

To unpack those questions, I tell a counterstory to the story that we keep telling about the mental health crisis in our prisons. I am not claiming that there are no crises, or mental health problems, in prisons or among prisoners. Rather, my claim is that the way we-government, corrections, also human rights litigators - keep telling that story buries the social-structural problems driving criminalisation and imprisonment: problems of ableism, poverty, colonialism, racism and patriarchy. It buries them under big clinical bags of prison/hospital fixes aimed at remedying a naturalised, individualised mental health crisis. Yet the solutions are not therethey are upstream, requiring systematic redress of social, political and economic inequality. For, I suggest (indeed, the evidence could not be clearer), the social determinants of decarceration and the social determinants of health are the same. ${ }^{5}$

The target of my critique is human rights litigation. I suggest that litigation strategies framed around the prison mental health crisis are getting in the way of our ability to address the social-structural determinants of criminalisation and imprisonment. ${ }^{6}$ More specifically, I argue that Canada's recent litigation around solitary confinement has diverted legal and political analysis from engagement with these determinants - colonialism, racism, patriarchy, capitalism, ableism - while ironically enabling the return of solitary confinement, if slightly re-described. Some may suggest this to be an endemic feature of institutional authority: the 'whack-a-mole' problem whereby as soon as institutionalised violence is putatively eradicated it reappears nearby

\footnotetext{
${ }^{4}$ See eg JR Sutton, 'The Political Economy of Imprisonment in Affluent Western Democracies,' (2004) 69 American Sociological Review 170.

${ }^{5}$ World Health Organization, 'The Social Determinants of Health: Introduction' online:

$<$ www.who.int/social_determinants/sdh_definition/en>.

${ }^{6}$ See S Wildeman, 'Agonizing Identity in Mental Health Law and Policy (Part II): A Political Taxonomy of Psychiatric Subjectification' (2016) 39(1) Dalhousie Law Journal 147; R Stanev and S Wildeman, 'Freedom: A Work in Progress' in E Flynn et al. (eds), Global Perspectives on Legal Capacity Reform (Oxford, Routledge, 2019).
} 
in slightly altered form. ${ }^{7}$ I argue that there is more to it than this. That is, I argue that the litigation strategies used in the fight against solitary confinement—strategies centred on liberallegal procedural protections and moreover on disability as the master category through which the harms of solitary are conceived - are partially responsible for these depressing results.

What this means for lawyers wishing to work in resistance to penal and disability-based incarceration is a question I address in my conclusion.

\section{Canada's Solitary Confinement Litigation}

\section{The Mental-Healthification of Prison Justice}

I begin by situating Canada's solitary confinement litigation in light of what we might call the mental-healthification of prison justice. By this, I mean persistent channeling of attention away from the interlocking oppressions affecting prisoner populations toward accounts focused on the mental health problems of prisoners and pronouncements that prisons are 'the new asylums'. ${ }^{8}$ As Liat Ben Moshe points out, such pronouncements push to the background the racialised, class-based and other patterns of oppression marking contemporary imprisonment while legitimating reforms aimed at expanding clinically-rationalised spaces of confinement and forced care. ${ }^{9}$

The way contemporary knowledge about prisoners is produced supports this dominant story. A 2013 Correctional Service Canada (CSC) study of federally sentenced men reported that 42.9 per cent (Ontario) to 60.1 per cent (Pacific) of those assessed met criteria for alcohol or substance use disorders, while 36.5 per cent (Ontario) to 63.8 per cent (Pacific) met criteria for antisocial personality disorder. ${ }^{10}$ Over 40 per cent reportedly had other major mental health diagnoses. As for women, a 2018 study found even higher prevalence across most categories:

\footnotetext{
${ }^{7}$ On reformist re-descriptions of solitary, see K Struthers Montford, K Hannah-Moffat and A Hunter, “"Too Wicked to Die": The Enduring Legacy of Humane Reforms to Solitary Confinement' in J Nichols and A Swiffen (eds), Legal Violence and the Limits of the Law (Oxford, Routledge, 2018) 141.

${ }^{8}$ L Ben Moshe, "Why Prisons are Not the New Asylums" (2017) 19 Punishment \& Society 272.

${ }^{9}$ ibid.

${ }^{10}$ Correctional Service Canada, Prevalence of Mental Health Disorders Among Incoming Federal Offenders: Atlantic, Ontario, \& Pacific Regions (Ottawa, CSC, 2013).
} 
Most women met criteria for a current mental disorder (79.2\%); among Indigenous women the rate was $95.6 \%$.... The most common anxiety disorder was for PostTraumatic Stress Disorder (PTSD) with almost one-third of the women meeting criteria. ${ }^{11}$

The Office of the Federal Correctional Investigator reported in 2015 that 30 per cent of federally sentenced women had previously been hospitalised for psychiatric reasons, and 60 per cent were using prescribed psychotropic medications. ${ }^{12}$

If we press beyond these statistics we begin to see other, social-structural forces at play. A recent study indicates that 65.7 per cent of women and 35.5 per cent of men incarcerated in Canada experienced abuse as a child, and that 50 per cent of women and 22 per cent of men experienced sexual abuse. ${ }^{13}$ Pressing deeper still, 15-20 per cent of Indigenous prisoners in the federal system attended residential schools. ${ }^{14}$ The colonialist legacy of separating Indigenous children from their families continues in child protection systems, with Indigenous, racialised and poor children starkly overrepresented in foster care. ${ }^{15}$ Incarcerated populations are, in turn, disproportionately comprised of persons raised in foster care. ${ }^{16}$

These rates of trauma and dislocation correlate with other forms of marginalisation. Canadian prisoners are disproportionately likely to have experienced poverty, homelessness, truncated education, and unemployment. ${ }^{17}$ Reflecting the complex co-incidence of social

\footnotetext{
${ }^{11}$ Correctional Service Canada, National Prevalence of Mental Disorders among Federally Sentenced Women Offenders: In Custody Sample (Ottawa, CSC, April 2018).

${ }^{12}$ Correctional Investigator of Canada, Annual Report of the Office of the Correctional Investigator 2014-15 (Ottawa, Office of the Correctional Investigator, 2015) 3.

${ }^{13} \mathrm{C}$ Bodkin et al. 'History of Childhood Abuse in Populations Incarcerated in Canada: A Systematic Review and Meta-Analysis’, (2019) 109(3) American Journal of Public Health e1.

${ }^{14}$ See F Kouyoumdjian et al., 'Health Status of Prisoners in Canada: Narrative Review' (2016) 62:3 Canadian Family Physician 215.

${ }^{15}$ C Blackstock, 'Residential Schools: Did They Really Close or Just Morph into Child Welfare?' (2007) 6(1) Indigenous Law Journal 71.

${ }^{16} \mathrm{~S}$ Trevethan et al., The Effect of Family Disruption on Aboriginal and Non-Aboriginal Inmates (Ottawa, Correctional Service of Canada, 2001) www.csc-scc.gc.ca/research/r113-eng.shtml.

${ }^{17}$ Kouyoumdjian et al., 'Health Status of Prisoners in Canada' 218. The statistics reported in this paragraph on the proportion of federally-sentenced prisoners who are Indigenous have been updated since this paper went to the publishers. See Ivan Zinger, Correctional Investigator of Canada, "Indigenous People in Federal Custody Surpasses 30\%: Correctional Investigator Issues Statement and Challenge” (News Release, January 21, 2020) at https://www.oci-bec.gc.ca/cnt/comm/press/press20200121-eng.aspx. On the proportion of federally-sentenced prisoners who are Black, see Correctional Investigator of Canada, Annual Report of the Office of the Correctional Investigator 2018-19 (Ottawa, Office of the Correctional Investigator, 2019) at 79, and Statistics Canada, Diversity of the Black population in Canada: An overview (Canada Minister of Industry, 2019) at 4. The 2018-19 OCI Report further indicates that "[s]ince 2010, while the population of White inmates has decreased by $23.5 \%$, the Indigenous population has increased by $52.1 \%$ " (at 65 ) and that "[ $\mathrm{t}]$ he female inmate population, despite a few small dips, has increased by $32.5 \%$ over the past ten years. (at 106).
} 
marginalisation with colonialism and status-based oppression, Indigenous persons constitute just 5 per cent of the population in Canada, yet over 30 per cent of all federally-sentenced prisoners and 42 per cent of federally-sentenced women are Indigenous. While just 3.5 per cent of the Canadian population is Black, 8 per cent of federal prisoners are Black.

Constructing the problem with Canada's prisons as a problem of prisoner mental health obscures these demographics — and with them, the social-structural determinants of criminalisation and imprisonment. At the same time, construction of the prison problem as a mental health problem opens the way for further carceral responses: hyper-rationalised clinicalcorrectional regimes offering securitised institutional responses to social-structural problems. Yet not only do prisons fail to rectify these problems, they intensify them-by disrupting already tenuous social supports, fragmenting families and communities, and subjecting those who are incarcerated to routine degradation and violence, sanctioned and unsanctioned. ${ }^{18}$

\section{Litigating Solitary}

Solitary confinement is defined under the Standard Minimum Rules for the treatment of prisoners (Mandela Rules) as "confinement of prisoners for 22 hours or more a day without meaningful human contact." 19 The Mandela Rules prohibit "prolonged solitary confinement ("in excess of 15 consecutive days" ${ }^{20}$ ) as well as any solitary confinement of "prisoners with mental or physical disabilities when their conditions would be exacerbated by such measures." ${ }^{21}$ In Canadian law, these expressions of international consensus have persuasive though not determinative force. ${ }^{22}$

\footnotetext{
${ }^{18} \mathrm{C}$ Wildeman and E Wang, 'Mass Incarceration, Public Health, and Widening Inequality in the USA' (2017) 389(10077) The Lancet 1464; World Health Organization, Prisons and Health (Copenhagen, WHO Regional Office for Europe, 2014); L Brinkley-Rubenstein, 'Incarceration as a Catalyst for Worsening Health' (2013) 1(1) Health Justice 3.

${ }^{19}$ UN General Assembly, United Nations Standard Minimum Rules for the Treatment of Prisoners (Mandela Rules): 8 January 2016, A/RES/70/175, Rule 44.

${ }^{20}$ Ibid.

${ }^{21}$ Ibid, Rule 45.2.

${ }^{22}$ See CCLA [ONCA] at paras $28 \& 29$.
} 
Solitary confinement is exemplary of carceral logics: use of incarceration/immobilisation to contain risks predictably arising within oppressive institutional and social structures. ${ }^{23} \mathrm{My}$ question is: Can litigation resist these logics? Or is it doomed to repeat them? To explore this, I turn to five recent Canadian cases challenging solitary confinement. Four relied on the Canadian Charter of Rights and Freedoms, while the fifth was brought (and settled) under Ontario's antidiscrimination legislation.

The most far-reaching of these cases were two public interest Charter challenges decided in 2017 in Ontario ${ }^{24}$ and 2018 in British Columbia (BC), ${ }^{25}$ and then taken on appeal. Together, the Ontario and BC appellate decisions establish the constitutional invalidity of federal correctional law permitting "administrative segregation": isolation of prisoners for up to 22 hours per day for indeterminate periods, on grounds of individual safety or institutional security. ${ }^{26}$

There were some differences in the two appellate-level judgments as to which Charter rights were infringed. However, there was no disagreement on the factual underpinnings of the litigation, namely that 'inmates held in prolonged administrative segregation are at risk of severe and often enduring negative health consequences', ${ }^{27}$ including permanent harm to mental health and social functioning and increased risk of suicide and self-harm. The courts further accepted that these risks are exacerbated if the individual has a pre-existing mental health condition. However, the two appellate courts refrained from pronouncing on exactly which mental health

\footnotetext{
${ }^{23}$ D Parkes, 'Solitary Confinement, Rights Litigation and the Possibility of a Prison Abolitionist Lawyering Ethic' (2017) 32:2 Canadian Journal of Law and Society 179.

${ }^{24}$ Corporation of the Canadian Civil Liberties Association v. Her Majesty the Queen, 2017 ONSC 7491 (CanLII) [CCLA (ONSC)], appeal allowed in part, Canadian Civil Liberties Association v. Canada (Attorney General), 2019 ONCA 243 (CanLII) [CCLA (ONCA)].

${ }^{25}$ British Columbia Civil Liberties Association v. Canada (Attorney General) 2018 BCSC 62 (CanLII) [BCCLA (BCSC)] var'd in 2019 BCCA 228 (CanLII) [BCCLA (BCCA)].

${ }^{26}$ Corrections and Conditional Release Act, SC 1992, c 2 [CCRA] ss. 31-33 and 37. Since this chapter went to press, the federal government discontinued its Supreme Court of Canada appeal of the two appellate-level decisions. See Supreme Court Docket 38574 (Attorney General of Canada v. Corporation of the Canadian Civil Liberties Association) reporting April 21, 2020 discontinuance joint with discontinuance of Docket 38814, at https://www.scc-csc.ca/case-dossier/info/dock-regi-eng.aspx?cas=38574. The federal government cites its understanding that legislation introduced last year instituting "Structured Intervention Units" has effectively abolished the administrative segregation regime that was under constitutional scrutiny. (See Patrick White, "Canada abandons solitary confinement appeal to Supreme Court" Globe and Mail (April 21, 2020), https:/www.theglobeandmail.com/canada/article-canada-abandons-solitary-confinement-appeal-to-supreme-court/.) As explored in the next section of this paper, that claim arguably takes the "whack-a-mole" dynamic of shifting solitary to new (clinically and procedurally rationalized, yet fundamentally unchanged), sites to a whole new level. ${ }^{27}$ CCLA (ONCA) at para 97. See also L Guenther, Solitary Confinement: Social Death and its Afterlives (Minneapolis, University of Minnesota Press, 2013).
} 
conditions are constitutionally inconsistent with administrative segregation, leaving this to caseby-case assessment.

The appellate courts identified two primary problems with the law: lack of independent review (contrary to principles of fundamental justice, given the liberty interests engaged), and lack of a determinate cap on the time one may be held in segregation (infringing liberty/security of the person per the court in $\mathrm{BC}$, and cruel and unusual treatment per the court in Ontario). On the second point, the BC Court of Appeal merely indicated that an appropriate cap must be fashioned, while the Ontario Court of Appeal looked to the Mandela Rules to establish a limit of 15 consecutive days. ${ }^{28}$

Discrimination was not among the rights considered in the Ontario litigation (although the rights infringements identified were anchored in evidence of harm to mental health). However, the $\mathrm{BC}$ trial judge declared the law discriminatory 'to the extent' that it permitted persons with 'mental illness/disability' to be segregated for any period. This was overturned at the BC Court of Appeal on the basis that the judge's concerns were with the law's application, not the law itself. The law, reasoned the Court, properly contemplated individualised assessment and accommodation. The problem was that correctional authorities had failed to meet their statutory obligation to 'give meaningful consideration to the health care needs of prisoners before placing or confirming the placement of prisoners in segregation'. ${ }^{29}$

A second discrimination-based ruling of the $\mathrm{BC}$ trial judge related to Indigeneity. He invalidated the law 'to the extent' that it authorised 'a procedure that results in discrimination against Aboriginal inmates', signaling concerns that risk assessment instruments or other correctional decision-making processes were contributing to Indigenous overrepresentation in solitary. Again, the BC appellate court disagreed, stating that while it accepted the evidence of overrepresentation, there was insufficient indication in the evidence or judgment of just what processes or instruments were to blame.

Importantly, further discrimination argumentation was raised by interveners, the Native Women's Association of Canada (NWAC) and West Coast Women's Legal Education and

\footnotetext{
${ }^{28}$ Above n19 Rule 45.

${ }^{29}$ BCCLA [BCCA] para 269.
} 
Action Fund (LEAF). They sought to highlight the impact of solitary confinement on federallysentenced Indigenous women through 'a robust contextual and intersectional framing of Indigeneity, of gender, and when appropriate, of disabling mental health impairments' ${ }^{30}$ The interveners argued that courts must recognise the unique ways solitary confinement reproduces and exacerbates interlocking oppressions affecting Indigenous women in order to remedy those harms. The BC trial judge rejected the arguments, relying on testimony that federally sentenced women have greater access to mental health treatments and Elders than do federally sentenced men. ${ }^{31}$ The appellate court did not challenge the judge's failure to engage the interveners' argument that solitary deepens social-structural oppressions in ways that cannot be segmented into singular or isolated 'grounds'. Instead, it adopted the still more formalistic position that intersecting grounds argumentation had not been placed directly in issue by the parties to the appeal. $^{32}$

In Ontario, a challenge to comparable practices was brought under provincial human rights legislation. Christina Jahn had been held in segregation in a provincial jail for 210 days, during which she missed cancer treatments and was denied supports for mental health conditions. ${ }^{33}$ While a psychiatric treatment centre was available to male prisoners, there women had no comparable facility. Jahn argued discrimination on combined grounds of gender and disability. The matter settled with the province committing to screen prisoners for mental health disabilities, provide access to treatment in jail, and exempt those with mental health disabilities from segregation except in cases of undue hardship. It also committed to publicly report on continuing segregation patterns and practices. ${ }^{34}$

In all of the above matters (notwithstanding the gender parity arguments in Jahn, and the intersectionality arguments of interveners LEAF and NWAC in the BC litigation), the damage of solitary confinement was ultimately narrowly framed as damage to mental health—whether exacerbation of pre-existing problems or creation of new ones. While the $\mathrm{BC}$ challenge had argued discrimination based in Indigeneity, that aspect of the claim was overshadowed and

\footnotetext{
${ }^{30} \mathrm{NWAC}$ and LEAF Factum at iii. BCCLA (BCCA) at paras 238-39; BCCLA (BCSC) at para 458.

${ }^{31} B C C L A(\mathrm{BCSC})$ at paras 456-463

${ }^{32}$ BCCLA (BCCA) at paras 238-39.

${ }^{33}$ Ontario Human Rights Commission, 'Segregation and mental health in Ontario's prisons: Jahn v. Ministry of Community Safety and Correctional Services', www.ohrc.on.ca/en/segregation-and-mental-healthontario $\% \mathrm{E} 2 \% 80 \% 99$ s-prisons-jahn-v-ministry-community-safety-and-correctional. 34 ibid.
} 
arguably undermined by an overwhelming concentration on a clinically mediated, individualised form of harm — to mental health.

Two other cases have brought mental health to the fore. One was a class action in respect of federal prisoners subject to administrative segregation while 'seriously mentally ill' ${ }^{35}$ In the words of the judge, these were 'the sickest of the inmates suffering from mental illness' ${ }^{36}$ The claimants established breach of Charter guarantees of liberty and security of the person as well as freedom from cruel and unusual treatment, based on lack of independent review and excessive time in segregation. Discrimination was not argued, yet pre-existing disability was clearly integral to class membership. Beyond individual damages, the court awarded 20 million dollars for vindication and deterrence, to be invested in 'additional mental health or program resources for structural changes to penal institutions'. ${ }^{37}$ In other words, the award was earmarked for prison-based accommodation of prisoners' mental health problems.

In the fifth case, ${ }^{38}$ the claimant, Adam Capay, was an Indigenous man who had been subjected to physical and sexual violence as a child and became dependent on drugs while incarcerated. At 19, he allegedly killed another prisoner during what appears to have been a delusional episode, possibly triggered by a medication change. He was then held in continuous segregation for 1,647 days awaiting trial. For months he was kept in a plexiglass cell with the lights on 24 hours a day, with no ability to flush the toilet from inside the cell, no television and no radio.

Capay brought a Charter claim seeking a stay of the murder charges against him. The stay was granted. The judge found that the effects of segregation on Capay's mental health had been extreme, including worsened PTSD and attention deficit hyperactivity disorder, and cognitive and memory impairment to the point of interference with his right to a fair trial. He declared that authorities had breached Capay's Charter rights to life, liberty and security of the person (by failing to afford him procedural protections, including independent review), his right against arbitrary detention (by failing to adhere to policy and employing continuous segregation

\footnotetext{
${ }^{35}$ Brazeau v. Attorney General (Canada), 2019 ONSC 1888 (CanLII) canlii.ca/t/hz9gd. A further judgment, released after this paper went to press, is Francis v. Ontario, 2020 ONSC 1644, upheld, 2021 ONCA 197. Francis is more radical than the judgments discussed herein, as it constitutionally prohibits placing persons with serious mental health disabilities in solitary confinement for any period (in the context of Ontario's administrative segregation regime).

36 ibid, para 5.

37 ibid, para 459. Award set aside as this chapter went to press, on the basis that 'it was not fair to either the class or Canada and it amounted to an unjustifiable assumption of judicial control over a complex public institution." (2020
} 
without evidence in support) and cruel and unusual treatment (here recognising the egregious harms to Capay's psychological and physical integrity).

Capay also established discrimination on the basis of mental health disability - ie, that segregation had exacerbated his mental health conditions, rendering him more susceptible to depression and suicide. Yet a further claim of discrimination on the basis of Indigeneity was rejected. Like the $\mathrm{BC}$ appellate court, the judge was unable to connect the dots between the violence and dislocation effected by colonialism, Indigenous persons' heightened vulnerability to criminalisation, incarceration and overrepresentation in solitary, and the claimant's individual circumstances. Specifically, the judge reasoned that the evidence had not established anything peculiar to Indigenous persons that would make their experiences of segregation markedly worse than others'.

\section{Three Worries (Carceral Resilience)}

In each case I have described, the harms of solitary are reduced from intensive exacerbation of interlocking oppressions to clinically mediated mental health problems. Correspondingly, at the remedial stage, this has given rise to three worries.

\section{(1) Screening as Net-Widening}

The first worry relates to mental health screening. Screening prisoners for mental health conditions is central to the Jahn settlement as well as the federal government's (ongoing) responses to the recent Charter challenges. Screening is also implicit in the Mandela Rules' exempting from solitary those whose mental health conditions are likely to be exacerbated. ${ }^{39}$

Why worry about screening? After all, it is potentially a mechanism of reasonable accommodation; disability must be identified before it can be accommodated. Yet the problem is that mental health screening is likely, in prison environments if not in general, to translate trauma and underlying social-structural oppression into individualised pathology and risk. In turn, this may be predicted to have a net-widening effect, ${ }^{40}$ justifying an increasingly stratified array of

\footnotetext{
ONCA 184 at para 112)

${ }^{38}$ R. v. Capay, 2019 ONSC 535.

${ }^{39}$ UN General Assembly, United Nations Standard Minimum Rules for the Treatment of Prisoners (2015).

${ }^{40}$ S Cohen, Visions of Social Control: Crime, Punishment and Classification (Cambridge, Polity Press, 1985) 41-42.
} 
enhanced restrictions across prison spaces and so a shift from solitary as state of exception to solitary (or multiple varieties of 'seg-lite') as rule.

The question for those promoting mental health screening as a throughway to prisoner mental health is: what will prevent it from simply becoming a justification for intensified security? Kelly Hannah-Moffat has shown how correctional knowledge has adapted actuarial risk/need assessment in ways that reconfigure complex and overlapping oppressions as reasons for intensified control. ${ }^{41}$ As Chris Cunneen observes, risk assessment substitutes for race/Indigeneity a set of ostensibly neutral markers - eg, family instability, involvement in the justice system, low education and employment attainment - with the effect of tracking inelastic patterns of material inequity while simultaneously performing race/Indigeneity against an implicit normative whiteness. ${ }^{42}$ I suggest that mental health screening is likely to be conscripted into the same carceral project of reconfiguring oppression as rationalised risk containment.

Two terms of Canada's correctional laws support the point. Section 17(e) of the Corrections and Conditional Release Regulations lists 'any physical or mental illness or disorder suffered by the inmate' as one of a set of factors to be taken into account in security classification (alongside, inter alia, 'outstanding charges', 'potential for violent behaviour', and 'continued involvement in criminal activities'). Such association of mental health conditions with risk and dangerousness is arguably inevitable in an environment oriented to order and control. Relatedly, s.18 mandates consideration of the 'degree of supervision and control' a person requires. This assessment, too, is likely to be informed by mandated mental health screening - indeed, this would seem to be a, if not the, fundamental point of screening.

In short, mental health screening, an integral part of the remedial responses provoked by the solitary confinement litigation, threatens to reify the sources of trauma and oppression while justifying the stratification of enhanced restrictions across prison spaces.

\section{(2) Out of the frying pan ...}

${ }^{41}$ K Hannah-Moffat, 'Sacrosanct or Flawed: Risk, Accountability and Gender-Responsive Penal Politics' (2010) 22(2) Current Issues in Criminal Justice 193.

${ }^{42}$ See eg C Cunneen, 'Youth Justice and Racialization: Comparative Reflections' (2019) 1 Theoretical Criminology 8 . 
A second worry in the wake of the solitary confinement litigation relates to alternatives; the 'out of the frying pan' problem. What sorts of alternatives are currently in place, and what alternatives are likely to emerge as administrative segregation recedes?

In December 2018, the federal government reformed its policy on administrative segregation. Those reforms exempted three categories of person: those with 'serious mental illness with significant impairment'; those 'actively engaging in self-injury which is deemed likely to result in serious bodily harm'; and those 'at elevated or imminent risk for suicide. ${ }^{43}$ But where are these exempted people to go?

The most obvious place is mental health observation. Federal correctional policy reserves mental health observation for prisoners 'at elevated or imminent risk for suicide,' 'actively engaged in self-injurious behaviour,' or 'identified by a health care professional as having a serious mental illness with significant impairment' ${ }^{44}$ Yet as Canada's Correctional Investigator has confirmed, mental health observation is at least as bleak and distressing as administrative segregation. ${ }^{45}$ Placement is preceded by strip search. ${ }^{46}$ On 'high watch', one is not entitled to personal items; on 'modified watch', this is discretionary. One has a right to a daily change of security gown but no right to shower. One is under constant surveillance by security camera. One is entitled to a mattress unless deemed at risk of using it in a self-injurious manner, in which case one sleeps on a thin blanket on the concrete slab bed. Feminine hygiene products may be deemed unduly risky, in which case women do without.

The other key characteristic of this alternative is lack of basic procedural protections. Framed as a therapeutic rather than a punitive or even administrative space, placement attracts no formal hearing. Instead one is given an opportunity to 'provide input' into one's placement plan. One is to be 'informed of the reason' for the placement and given 'reasonable access to relevant documentation'. However, there is no right to counsel or duty to facilitate access to counsel; instead one is allowed 'an advocate' defined as 'a person who, in the opinion of the Institutional Head, is acting or will act in the best interest of the inmate'. A review process is started,

\footnotetext{
${ }^{43}$ CD 709 (last update 2017-08-01) s.19 (a) \& (b). Barring 'exceptional circumstances', pregnant prisoners, those with significant mobility impairment, and those in palliative care, are also exempt.

${ }^{44}$ CD-843 (last update 2017-08-01) s.10.

${ }^{45}$ Risky Business: An Investigation of the Treatment and Management of Chronic Self-Injury Among Federally Sentenced Women Final Report (Ottawa, ON: OCI, 2013) 17-22.

46 ibid, 19.
} 
gradually moving up the command-chain of correctional mental health; however, neither the individual nor their advocate or counsel is directly engaged in that. ${ }^{47}$

There is no formal cap on time in mental health observation. However, in practice, difficult-to-manage prisoners are likely to be shifted among intensely restrictive regimes within the prison (e.g., back and forth between administrative segregation - or simulacra thereof - and medical observation) and/or other closely supervised clinical-correctional spaces. ${ }^{48}$

\section{$\underline{\text { Other Alternatives }}$}

Reports on mental health care in Canada's correctional systems routinely emphasise the insufficiency of resources, staffing, and facilities to meet the needs of prisoners. ${ }^{49}$ Thus alternatives to segregation and/or mental health observation are few. In the federal context, men deemed highest risk may be transferred to the Special Handling Unit ${ }^{50}$ (a supermax prison in Quebec) or one of five Regional Treatment Centres. ${ }^{51}$ Women may be placed in one of the Structured Living Units in the women's prisons or transferred to the Regional Psychiatric Centre in Saskatoon. Transfer to a provincial psychiatric hospital is possible if the prisoner (and hospital/province) is willing, or without the prisoner's consent should they meet provincial involuntary hospitalisation criteria. ${ }^{52}$

Each of these alternatives is itself a site of intensive confinement and control. In 2017, an independent review of the Regional Treatment Centres identified 'low staffing ratios to patient needs' which 'can result in the overuse of segregation and clinical seclusion practices'. ${ }^{53}$ While advocates tend to view provincially run psychiatric hospitals as the best alternative, ${ }^{54}$ these sites,

\footnotetext{
${ }^{47}$ CD-843, ss.11-15.

${ }^{48}$ See, e.g., Risky Business, above $\mathrm{n} 45$ at 10.

${ }^{49}$ See Office of the Correctional Investigator, Priority: Access to Physical and Mental Health Care (2016) www.oci-bec.gc.ca/cnt/priorities-priorites/health-sante-eng.aspx.

${ }^{50}$ CD-708 (Special Handling Unit) (last update 2018-09-10).

${ }^{51}$ CD-706 (Classification of Institutions) (last update 2018-11-07).

52 Guidelines 710-2-3 (Inmate Transfer Process) www.csc-scc.gc.ca/acts-and-regulations/710-2-3-gl-en.shtml.

${ }^{53}$ OCI Report 2017-18 at 21-22.

${ }^{54}$ See eg West Coast Prison Justice Society/Prisoners Legal Services, Damage/Control: Use of Force and the Cycle of Violence and Trauma in BC's Federal and Provincial Prisons (2019) www.prisonjustice.org/news-release-reportcalls-use-of-force-practices-in-bc-and-federal-prisons-traumatic-and-harmful-and-makes-recommendations-forchange/).
} 
too, commonly engage in restrictive practices, typically with few or no procedural protections. ${ }^{55}$ Between 2006 and 2010, one in four psychiatric inpatients in Ontario were subject to physical or chemical restraints or seclusion. ${ }^{56}$ Deaths precipitated by use of restraints in provincial psychiatric and forensic hospitals have attracted inquiry processes revealing systemic discrimination (including on intersecting race and disability grounds) in conditioning use of force. ${ }^{57}$ Beyond these overt material forms of control is the further element of bio-psychological control, through psycho-pharmaceuticals or other mechanisms that have proven even less susceptible to liberal-legal rights protections than the material and spatial restrictions of solitary confinement. $^{58}$

The Future?

Recently added (June 2019) to the above alternatives is a law reform measure through which Canada purports to have abolished solitary confinement. ${ }^{59}$ The legislation introduces Structured Intervention Units (SIUs). Prisoners may be placed in SIUs on the same bases as administrative segregation: safety and security. They are entitled to four hours outside cell daily instead of two, including two hours of 'meaningful human contact'. However, discretionary exceptions exist, including on security grounds. Other factors distinguishing SIUs from administrative segregation are a more active role for health professionals in making recommendations about placement and a new (rather convoluted) system of administrative oversight.

\footnotetext{
${ }^{55}$ See L Johnson, Operating in Darkness: BC's Mental Health Act Detention System (Vancouver, CLAS, 2017); I Grant and P Carver, "PS v Ontario: Rethinking The Role of the Charter in Civil Commitment" (2016) 53(3) Osgoode Hall Law Journal 999; CT Sheldon, K Spector \& M Perez, "Re-Centering Equality from the Inside: The Interplay Between Sections 7 and 15 of the Charter in Challenges to Psychiatric Detention" (2016) 35:2 National Journal of Constitutional Law 19.

${ }^{56}$ TM Mah et al, 'Use of Control Interventions in Adult In-Patient Mental Health Services' (2015) 28(4) Healthcare Management Forum 139-145.

${ }^{57}$ Ontario Human Rights Commission, 'OHRC Settlement with the Waypoint Centre for Mental Health Care: A step towards respecting the human rights of diverse patients' (2017) www.ohrc.on.ca/en/news_centre/ohrc-settlementwaypoint-centre-mental-health-care-step-towards-respecting-human-rights-diverse. See also Ontario Coroner's Inquest into the Death of Jeffrey James, www.empowermentcouncil.ca/PDF/Jeffery\%20James\%20Inquest.pdf. ${ }^{58}$ See L Steele, 'Temporality, Disability and Institutional Violence: Revisiting In Re F' (2017) 26:3 Griffith Law Review 378.

${ }^{59}$ An Act to amend the Corrections and Conditional Release Act and another Act, S.C. 2019, c. 27
} 
Senator Kim Pate has observed that in many institutions SIUs are simply rebranded administrative segregation units. ${ }^{60}$ Beyond this are concerns about continued broad discretion (eg, to deny time out of cell); the fact that oversight powers rest in non-judicial bodies (which may, moreover, deny prisoners an oral hearing); lack of a hard time limit for placement; and lack of a clear duty on authorities to facilitate access to counsel. In short, the new regime, like the old, is tilted toward intensive security and light-touch review, even as it takes cover behind enhanced mental health and behavioural monitoring.

Similar concerns arise around policy changes in Ontario. The Placement of Special Management Inmates policy creates four categories of placement for prisoners deemed unsuited for the general jail population: behavioural care, managed clinical care, stabilisation, and supportive care. ${ }^{61}$ According to Justice David Cole, one of two experts appointed to oversee Ontario's compliance with the Jahn settlement:

Though it is hoped that these policy changes will bring about significant changes to the segregation regime, unfortunately it is entirely possible that inmates (mentally ill or not) who were previously housed for lengthy periods of time in either 'administrative' or 'disciplinary' segregation, may now be routinely housed in 'behavioural care', where they may cycle in and out of these two statuses, merely with time frames superficially adjusted, accompanied by reams of paperwork to justify maintenance of much of the status quo. ${ }^{62}$

Again, the worry is that these so-called alternatives are but repackaged versions of solitary confinement, now with the legitimising veneer of clinical knowledge.

\section{(3) The Remainder}

A last worry takes us back to the imperative of disability non-discrimination: an imperative reflected in the Mandela Rules and in Jahn, in the BC solitary confinement litigation and in Capay. It is the anti-discrimination imperative that informs the international prohibition on any solitary confinement of prisoners with mental health conditions. Yet, while the worry

\footnotetext{
${ }^{60}$ Teresa Wright, 'Senator Says Solitary-Confinement Bill Will Make some Conditions Worse, not Better' (2019) Canadian Broadcasting Corporation www.cbc.ca/news/canada/kitchener-waterloo/senator-says-solitaryconfinement-bill-will-make-some-conditions-worse-not-better-1.5124649.

${ }^{61}$ Justice D Cole, Interim Report [Jahn Settlement] at 23, 39-42 http:/www.ohrc.on.ca/sites/default/files/Interim\%20Report\%20-\%20Compliance\%20with\%20Jahn.pdf. $62 \mathrm{ibid,} \mathrm{41.} \mathrm{'As} \mathrm{one} \mathrm{difficult} \mathrm{remand} \mathrm{prisoner} \mathrm{awaiting} \mathrm{trial} \mathrm{in} \mathrm{an} \mathrm{institution} \mathrm{where} \mathrm{some} \mathrm{of} \mathrm{these} \mathrm{changes} \mathrm{have}$ already been instituted recently said in my court: "all this is b.s.; it's just seg. lite"” (ftn52).
} 
above was that alternative sites for those deemed mental health affected may be as bad or worse, the present worry is for those left behind. For once an exceptional class uniquely vulnerable to the harms of solitary confinement is extracted, those who remain are in an important sense positioned as fit for it.

That is, just as there are complexities around defining disability, so is there complexity around construction of those who do not qualify for disability-based accommodations. Here one must be particularly attentive to the propensity for racialised identification of those fit for hard time. Michael Martin, in a study of mental health screening of federal prisoners in Canada, reports greater resistance to screening on the part of racialised and Indigenous prisoners. ${ }^{63}$ One may speculate on the reasons for this: eg, cultural or socio-political differences in interpreting or valuing psychiatric knowledge, association of psychiatry with colonial power, concerns about appearing vulnerable. An Indigenous elder testifying in the BC litigation made the straightforward suggestion that prisoners resist mental health diagnoses out of fear they will be sent to a treatment centre. ${ }^{64}$

These insights are deepened in the work of Jasbir Puar, who identifies a category constructed in the shadow of successful disability rights claims she calls debility. Debility is the remainder: 'bodies sustained in a perpetual state of debilitation precisely through foreclosing the social, cultural, and political translation to [legally recognized, materially resourced] disability' ${ }^{65}$ In this vein, a recent report on use of force in federal and provincial prisons in BC describes the case of 'Joey', an Indigenous man who lost his primary caregivers as a child and has spent much of his life in solitary. Joey describes an incident during his time in youth detention:

I remember the staff taking me down, twisting me up, banging my head against the floor, and putting me in straps. They hit my head so hard on the ground that my mouth would bleed. The straps were kind of like a Pinel bed or a straitjacket, but my legs were strapped together tight and pulled up to my chest. They would leave me like that and put me in an observation cell for a long time while they sat and watched me. ${ }^{66}$

\footnotetext{
${ }^{63} \mathrm{M}$ Martin, Detection and Treatment of Mental Illness Among Prison Inmates: A Validation of Mental Health Screening at Intake to Correctional Service of Canada (Ottawa, University of Ottawa, 2017).

${ }^{64}$ BCCLA (BCSC) para 233.

${ }^{65}$ J Puar, The Right to Main: Debility, Capacity, Disability (Durham NC, Duke University Press, 2017) xiv.

${ }^{66}$ West Coast Prison Justice Society/Prisoners Legal Services, Damage/Control (2019) 5.
} 
Joey has spent over 2,100 days in federal segregation (and further time in segregation in provincial custody). He has been subject to frequent use of force, typically precipitated by selfharm. He has been diagnosed with PTSD and major depressive disorder. ${ }^{67}$ Yet, one of the deepest challenges in this and other cases is obtaining the requisite professional approval for transfer from a correctional to a clinical site. The potential is always there for prisoners to be classed as drug-seeking or attention-seeking, or simply disruptive, violent or offensive rather than actually 'sick'. Louisa Smith and Leanne Dowse elaborate on this dynamic, which they argue particularly affects persons subject to oppression on intersecting bases across multiple institutional sites. ${ }^{68}$ Their argument reminds us that the clinical and correctional knowledges giving shape to the carceral archipelago are in a sense mirror images, working together to reduce complexity to justifications for confinement and control.

The claims-making device of disability discrimination — at least, detached from analysis of the social-structural foundations of disability and other forms of oppression-may paradoxically reinforce this way of sorting prisoners/patients. The worry is in part that in remediating disability discrimination we deepen the oppression of those not qualifying as disabled. The further worry is that surrendering the field of prison justice to a clinically-mediated 'disability' masks the complexity of both the mental health affected and the class(es) deemed fit for segregation or other security-centric treatment.

\section{Conclusion}

I have argued that recent Canadian litigation intent on bringing solitary confinement under the sway of human rights has proven an unwitting means of strengthening carceralinstitutional resilience. That is, this litigation has permitted reductive translation of the problem of solitary - a problem inextricably imbricated in histories of trauma and oppression, in colonialism, racism, patriarchy, ableism and interacting with all of these, capitalist classism - to a 'mental health' problem inviting a clinical (or correctional-clinical) fix. Such reductivism is apparent not simply in the way the courts have dealt with disability discrimination, but also

\footnotetext{
67 ibid.

${ }^{68}$ L Smith and L Dowse, 'Complexity and Disability: Drawing from a Complexity Approach to Think Through Disability at the Intersections' in Katie Ellis et al. (eds), Interdisciplinary Approaches to Disability: Looking Towards the Future (Abingdon UK, Routledge, 2019) 123.
} 
breach of security of the person and cruel and unusual treatment. Common to all these human rights-based successes has been relinquishing of the field of justice to individualised clinical knowledge.

Does this mean that law, or human rights litigation, is doomed to reproduce carceral logics - to be a mechanism of carceral control? Arguably, as with any institution, law can be a site of resistance. In closing I turn to Debra Parkes, from whose work I draw three imperatives of anti-carceral lawyering: expose institutional violence while establishing solidarity with those inside; surface intersectional oppression; and seek anti-carceral remedies. ${ }^{69}$ Canada's solitary confinement litigation has contributed in important ways to the first of these imperatives. However, it has failed (so far) on counts two and three.

Anti-carceral lawyering requires that we work backwards from anti-carceral remediesand that we do so in solidarity with prisoners and others across the carceral archipelago, united by a commitment to intersectional substantive equality. It expresses a radical lawyering ethic grounded in the aspirations and capacities of specific communities to resist incarceration and fashion radical alternatives. It requires a willingness to devise strategies in and beyond the courts and to seek remedies reaching beyond the material sites of incarceration. ${ }^{70}$ At the same time, lawyers aspiring after an anti-carceral ethic should cultivate familiarity with the insights of both prison abolitionism and critical disability theory, in order to resist (and advise resistance to) strategies that obscure the justice claims of those located at one or the other side of the prison justice/disability justice divide.

Last, pursuit of anti-carceral remedies requires challenging conceptions of disability, or mobilizations of this concept or identity category in law, which would isolate disability from social-structural injustice in ways that invite individualising and pathologising 'remedies'. This means busting disability out of solitary and situating disability-based justice claims within a broader account of intersectional substantive (transformative) equality. Ultimately, cracking the foundations of solitary confinement requires us to rethink disability, justice, and human rights in a way that is mindful of intersecting oppressions as well as liberations.

\footnotetext{
${ }^{69}$ Parkes, 'Solitary Confinement' (2017).

${ }^{70}$ In Canada, this work may be informed by ss. $81 \& 84$ of the CCRA, above n22. These provisions enable Indigenous communities to enter into agreements with Canada to develop community-based strategies for supervising persons under sentence or on parole/statutory release.
} 